\title{
The effect of principal supervision and teacher work motivation on teacher job satisfaction
}

\author{
Rina Dwi Maryanti ${ }^{1}$, Yasir Arafat ${ }^{2}$, Syaiful Eddy ${ }^{2}$ \\ ${ }^{1}$ Sekolah Dasar Negeri 2 Sidorahayu, Plakat Tinggi, Indonesia \\ ${ }^{2}$ Universitas PGRI Palembang, Indonesia
}

\begin{tabular}{l} 
Article Info \\
\hline Article history: \\
Received Jul $14^{\text {th }}, 2021$ \\
Revised Aug $19^{\text {th }}, 2021$ \\
Accepted Aug $30^{\text {th }}, 2021$ \\
\hline Keyword: \\
Supervision \\
Teacher work motivation \\
Teacher job satisfaction \\
\hline
\end{tabular}

\begin{abstract}
The article aimed to determine and analyze the effect of Principal Supervision, Teacher Work Motivation on Job Satisfaction of Public Elementary School Teachers at Plakat Tinggi District. This type of research was descriptive quantitative. The sample in the study was 140 respondents with data collection techniques in the form of a questionnaire (questionnaire). The results showed that: 1) there was a significant effect of principal supervision on teacher job satisfaction, 2) there was a significant effect of teacher work motivation on teacher job satisfaction, 3) there was a significant influence between principal supervision and teacher work motivation on job satisfaction teacher.
\end{abstract}

(C) 2021 The Authors. Published by IICET.

This is an open access article under the CC BY-NC-SA license (https://creativecommons.org/licenses/by-nc-sa/4.0

\section{Corresponding Author:}

Maryanti, R. D.,

Sekolah Dasar Negeri 2 Sidorahayu, Plakat Tinggi, Indonesia

Email: rinadwimaryanti669@gmail.com

\section{Introduction}

Educators are professionals who are in charge of planning and implementing the learning process, assessing learning outcomes, conducting guidance and training, and conducting research and community service, especially for educators in tertiary education. Education is a process of providing assistance to human learners to develop thinking power, sense power, function power and their role in life. An adequate educational process is needed to support the realization of these noble hopes. However, the results of the education process cannot be felt immediately, but it takes a long time, throughout life, and touches all aspects of life in society, so that it becomes an identity for the progress, justice and prosperity of the nation. This is reflected in the Republic of Indonesia Law Number 20 of 2003 concerning the National Education system, in Chapter 1 article 1 paragraph 2 it is stipulated that "National education is education based on Pancasila and the 1945 Constitution which is rooted in religious, cultural values. and responsive to the demands of changing times ".

According to [1], education is an effort that is to educate, guide, foster, influence, and direct with a set of knowledge that can be done formally (in school) or informally (within the family and environment.[1][2] So far, there are only a portion of the Principals who have good qualifications in terms of school majerials.[2] In addition, there are still many school principals who are not yet correct in implementing their function as administrator. The number of Principals who have not implemented their functions is related to many things, for example related to the human resources of the Principal, the geographical situation of the school and the assumption that the Principal is everything in the school, and so on. This assumption creates the teacher's view that a principal is a person who needs to be respected, praised and trusted [3][4]. This raises the distance between the principal and the teacher at school. Of course, this creates a less harmonious work atmosphere. 
Leadership involves a process of social influence, in which case a deliberate influence is exercised by a person on others to structure activities and relationships within a group or organization [5]. In other words, everything that a person does, sees, and experiences in everyday life is an educational process. Herabudin reveals that activities in education, one of which, are directly related to educators or teachers or lecturers who are human elements in education [6]. Educators are human figures whose presence and role are expected in education, as sources who occupy positions and hold important roles in education.

Therefore, educational unit institutions are required to be able to produce quality graduates who are able to think, behave, behave and have skills in accordance with the demands of the times. All of this will certainly be realized if educational institutions are able to select and place professional educational personnel. The regulations on teachers and lecturers in the Law on National Education System (National Education System) No. 20 of 2003, article 39 paragraphs 1 and 2 in Mulyasa (2011), states that: Education personnel are tasked with carrying out administrative, management, development, supervision and technical services to support the educational process in an education.

Damayani, argue that job satisfaction and work motivation felt by teachers and employees can reduce organizational commitment or increase the organizational commitment of teachers and employees [7][8]. To get work motivation, a motivator is needed. This is the result of thoughts and wisdom contained in integrated planning and programs that are adapted to conditions and situations. Job satisfaction is a reflection of feeling happy for someone (including the teacher) after he / she has done a certain job in earnest which is reflected in the form of pride because the job is as expected and gives positive feedback to him. This means that in job satisfaction there is seriousness in working, there is pleasure in doing and there is feedback (feedback) which is certainly beneficial for the worker. People pay less attention to less responsibility for unattractive and unsatisfactory workers. Unpaid workers create unhealthy conditions that are dangerous to the individual concerned, to the organization and to society at large. Whether we realize it or not, the existence of seriousness in working or being happy with the subject being done is in many ways determined by the positive feedback mentioned above, for example in the form of intensive rewards, bonuses, prestige and promotions.

The principal is one of the components of education that has the most role in improving the quality of education [9]. As [10] "There is a close relationship between the quality of the Principal and various aspects of school life such as school discipline, school culture climate, and a decrease in students' naughty behavior"[10]. Meanwhile, teachers play an important role in developing and improving the quality of education. Quality teachers are expected to develop quality learning and produce quality outputs. Ideally every educational institution not only demands a lot of teachers, but on the contrary, it must be accompanied by meeting the needs of the teacher, giving awards both orally, in writing and in the form of valuable goods, improving welfare (transportation, children's education allowances, health benefits, and intensive care. Others).

There is a symbiosis of mutualism or a mutually beneficial relationship. The management also participates in relation to teacher job satisfaction in conducting intensive interpersonal communication, not discussing the weaknesses of a teacher in general meetings, polite in speaking and arguing without emotion. We can define motivation in terms of one's behavior. Motivated people will put in more effort than those who are not. However, this definition is relative and gives us little explanation. A more descriptive but less substantive definition says that motivation is the desire to do something and determines the ability to act to satisfy individual needs. A need, in terminology, means a physical or psychological deficiency that makes a certain output look attractive.

Based on preliminary observations at SD in Plakat Tinggi District, the leadership or principal should pay attention to and need to increase motivation to all teachers, because the motivation given to teachers at SD in Plakat Tinggi District is still very lacking. This indication reflects the teacher's lack of concern for their duties, often complains and always thinks that every job given is complicated, there is no desire to be motivated and achieve. This can be seen from the increasing slackness of work, there are still teachers who use their working time to do things outside their work, there are teachers who leave the office during working hours.

Based on the background of the above problems, researchers are interested in knowing more about "The Effect of Principal Supervision and Teacher Work Motivation on Primary School Teacher Job Satisfaction in Plakat Tinggi District"

\section{Method}

According to [11], the research method is a series of methods or activities for conducting research based on basic assumptions, philosophical and ideological views, questions and issues at hand. The research method 
has a specific research design. This research method is quantitative research by describing the research findings.

Quantitative research is based on the philosophy of positivism which emphasizes objective phenomena and is studied quantitatively. The sample in this study is the SD Negeri in Plakat Tinggi District, with the sampling in this study using proportional random sampling, namely teachers who are used as research samples are teachers in each elementary school with a total of 140 teachers. In collecting data, techniques are needed, both techniques in providing data, and techniques in classifying the data that has been collected. The same thing was also stated by [12] that the data collection method is a method used to collect data, while the data collection technique is the method used in carrying out the method that has been chosen which uses questionnaire data and documentation. The data analysis technique in this study used simple correlation and multiple regression data analysis techniques with the help of the SPSS For Windows Version 22 program. The analysis implementation stage included: (1) descriptive analysis, (2) analysis requirements test, and (3) hypothesis testing.

\section{Results and Discussions}

Hypothesis testing was continued after testing the data analysis requirements, namely the normality test and the homogeneity test. After the data is declared to have met the requirements to be tested, then the hypothesis is tested using the $t$ test and the $F$ test, to determine the effect partially and simultaneously on the variables to be tested

Table $1<$ The results of the t-test analysis for variables (X1) on $\mathrm{Y}>$

\begin{tabular}{lccccc}
\hline \multicolumn{7}{c}{ Coefficients $^{\mathbf{a}}$} & & & \\
Model & \multicolumn{2}{c}{$\begin{array}{c}\text { Unstandardized } \\
\text { Coefficients }\end{array}$} & $\begin{array}{c}\text { Standardized } \\
\text { Coefficients }\end{array}$ & $\mathrm{t}$ & Sig. \\
& $\mathrm{B}$ & Std. Error & Beta & & \\
(Constant) & 31.044 & 12.019 & & 2.583 & .011 \\
Supervision & .690 & .144 & .377 & 4.786 & .000 \\
\hline
\end{tabular}

a. Dependent Variable: Teacher Work Satisfaction

Source: Processed Results of the SPSS Program version 22 of 2020

Table $2<$ Results of the F Test Analysis ANOVA $>$

\begin{tabular}{llccccc}
\hline Model & & Sum of Squares & Mean Square & F & Sig. \\
1 & Regression & 1555.249 & 2 & 777.624 & 23.23 & .000 \\
& Residual & 4585.722 & 137 & 33.472 & 2 & $\mathrm{~b}$ \\
& Total & 6140.971 & 139 & & & \\
\hline
\end{tabular}

a. Predictors: (Constant), Job Satisfaction (X2), Compensation (X1)

b. Dependent Variable: Teacher Performance (Y)

Based on the above values, it is known that the significance value for the effect of $\mathrm{X} 1$ and $\mathrm{X} 2$ simultaneously or together on $\mathrm{Y}$ is equal to $0.000<0.005$ and the $\mathrm{F}$ value of $33.472>\mathrm{F}$ table 2.69 , so it can be concluded that Ha 3 is accepted, which means that there is a significant influence $\mathrm{X} 1$ and $\mathrm{X} 2$ together against Y.

Based on the results of the description of the research data analysis in CHAPTER IV using the SPSS program version 22. Before the research was carried out, the data requirements were tested first, namely the validity test and the reliability test. The data validity test was conducted by using the validation test which was carried out with the validator, namely PGRI Palembang University lecturers. Then proceed to test the validity of the analysis using the calculation of the SPSS version 22 program. The results of the calculation of the analysis validation for the principal's supervision variable, it is known that all of them are valid so that the statement items can be tested further. The results of the calculation of the validation analysis for the teacher work motivation variable note that all of them are valid so that the statement items can be tested further. The results of the calculation of the validation analysis for the teacher job satisfaction variable note that all of them are valid so that the statement items can be tested further. Then the data prerequisite test is continued to the reliability test. After calculating using the SPSS version 22 program, it is known that the principal supervision 
variable obtained a value greater than the $r$ table, the teacher work motivation variable was greater than the $r$ table, and the teacher job satisfaction variable obtained a value greater than the $r$ table so it could be concluded that all variables the research is declared reliable [13].

\section{Conclusions}

Based on the results of the research that has been done, it can be concluded that the supervision of the principal has an effect on teacher job satisfaction based on the results of the test analysis. This shows that there is an effect of principal supervision on the job satisfaction of elementary school teachers in Plakat Tinggi sub-district which has answered the first hypothesis. Teacher work motivation has an influence on teacher job.

Thanks are given to your family and friends, the Chancellor of the PGRI Palembang University, the Director of the PGRI Palembang University Postgraduate Program, the Chair of the PGRI Palembang University Education Management Masters Study Program and the supervisors who have helped in the completion of this journal which is a product of the thesis. Then thank you also to the friends of the PGRI Palembang University Postgraduate students and all those who have helped write and publish this journal.

\section{References}

Alhusaini. A, Kristiawan. M and Eddy. S (2020). The Effect of Work Motivation and Work Discipline on Teacher Performance. Islamic Education Journal. Vol. 1, No. 3, June 2020. E-ISSN: 2745-9977

Damayani, Titin., Arafat, Y. and Eddy, S. (2020). The Influence of Principal Leadership and Work Motivation on Teacher

Arlita, S. E., Ahyani, N., \& Missriani, M. (2020). Pengaruh Kompetensi Akademik dan Motivasi Guru Terhadap Kinerja Guru. Attractive: Innovative Education Journal, 2(3), 8-14.

Sumarsono, S., Subandi, S., \& Imam, S. I. (2021). The Role of School Principal in Learning Islamic Religious Education in SD Negeri 01 Kayu Batugunung Labuhan Way Kanan. Bulletin of Pedagogical Research, $1(1), 54-69$.

Umam, W. (2020). Kepemimpinan Kiai dalam Mengembangkan Pondok Pesantren. Attractive: Innovative Education Journal, 2(3), 61-69.

Damayani., Arafat, Y., \& Eddy, S. (2020). Pengaruh Kepemimpinan Kepala Sekolah dan Motivasi Kerja terhadap Kinerja Guru Titin Journal of Innovation in Teaching and Instructional Media Vol. 1 No. 1, Page: 46-57.

Herabudin, 2009, Administration and Supervision of Education, Bandung: CV. Faithful Library.

Purwana, D., Ahmad, A., \& Saptono, A. (2020). The Influence of Leadership and Work Environment toward Organziational Citizenship Behavior (OCB) through Work Satisfaction. International Journal on Advanced Science, Education, and Religion, 3(2), 57-71.

Romlah, O. Y., \& Latief, S. (2021). Empowering the Quality of School Resources in Improving the Quality of Education. Bulletin of Science Education, 1(1), 37-41.

Marce.S, Ahmad.S \& Eddy. S (2020). Leadership Management of Principals as Administrators in Increasing Teacher Competence. Dawuh Islamic Education Journal: Vol. 1, No. 2, July 2020

Mulyasa, E. (2017). Become a Professional School Principal. Bandung: Youth Rosdakarya

Sugiyono. (2018). Quantitative Research Methods. Bandung: Alfabeta. Sukmadinata, N. S. (2015). Educational Research Methods. Bandung: Youth Rosdakarya

National Education System Law No. 20 of 2003 